Zh.S. Kassymova, L.K. Orazzhanova, B.B. Bayakhmetova, B.S. Gaisina, N.B. Kassenova, G.T. Yelemessova

Shakarim State University of Semey, Kazakhstan

(E-mail: bulbul.bayahmetova@mail.ru)

\title{
Preparation of interpolymer complexes of chitosan and sodium alginate
}

\begin{abstract}
The method of synthesis of new cheap and biodegradable soil former - an interpolymer complex (IPC) based on natural polymers has been developed for the first time. To solve environmental problems biocompatible with living tissues, bioinert natural polymers - polysaccharides chitosan (CS) and sodium alginate (AL) were used as structural components of the IPC. The chitosan-sodium alginate IPC was prepared by mixing equimolar solutions of polymers in a given proportion. The composition and properties of the prepared polymer complexes - mass, electrical conductivity, mechanical properties, rheological properties, size and particle charge, structure were determined by physicochemical methods (reoviscosimetry, mechanical analysis, gravimetry, potentiometric and conductometric titration, dynamic light scattering and Fourier-transform infrared spectroscopy). The composition of the chitosan - sodium alginate complex CS: AL is 1:4. It is established that the formation of an interpolymer non-stoichiometric complex occurs as a result of ion-ion interactions. Films based on IPC of CS and AL were prepared and mechanical properties of this films were detected. Films based on interpolymer complex have higher mechanical strength than films of individual polymers. Therefore, this polymer system is a promising material for the use it in preventing wind and water migration of lands.
\end{abstract}

Keywords: complexation, biopolymers, chitosan, sodium alginate, composition, nonstoichiometric complex, films, polyionic complexes.

\section{Introduction}

The production of new functional materials with a wide range of practical application is one of the main challenges of modern science. From a scientific and practical point of view there is a special interest to interpolymer complexes. IPCs possess a complex of unique physicochemical, colloidal and mechanical properties which are promising for the use in various fields of science, engineering, medicine and agriculture [1-3].

As known, IPCs are the products of the interaction between chemically complementary polymers which form a large number of intermolecular bonds such as hydrogen, electrostatic, ion-dipole, Van der Waals, and hydrophobic interactions [4].

The formation of IPC occurs in aqueous solutions through the binding of counter-ions with the ionization of their reactive functional groups. The initial complexing polyelectrolytes contain ionic functional groups, amount and relative position of which affect the thermodynamics of complexation and control stability, define the structure and properties of IPC [5].

Interpolymer complexes based on natural polymers represent an extensive class of polymer compounds, which due to their biodegradability, biocompatibility and non-toxicity find practical application as structurebuilders for disperse systems, materials for medical and biotechnological purposes, medicines, etc. [6-11]. Biopolymers like chitosan (polycation) and sodium alginate (polyanion) arouse interest among natural polymers capable of forming polymer-polymer complexes.

Chitosan (poly $\beta-1,4-2$-deoxy-2-amino-D-glucopyranose) is the product of deacetylation of natural chitin polysaccharide (Fig. 1).

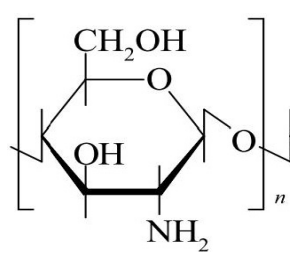

Figure 1. The structural formula of chitosan 
It is known $[12,13]$ that the presence of amino groups defines the behavior of chitosan in solution as a weak cationic polyelectrolyte and it has $\mathrm{pH}$-dependent solubility (it is easy to dissolve in acidic environments and not to dissolve in neutral and alkaline environments).

Sodium alginate is an ionic polysaccharide obtained by alkaline extraction of brown algae, due to the complex of very valuable properties in practical terms (water solubility, non-toxicity, high thickening ability) holds one of the leading positions among water-soluble polymers of natural origin (Fig. 2).

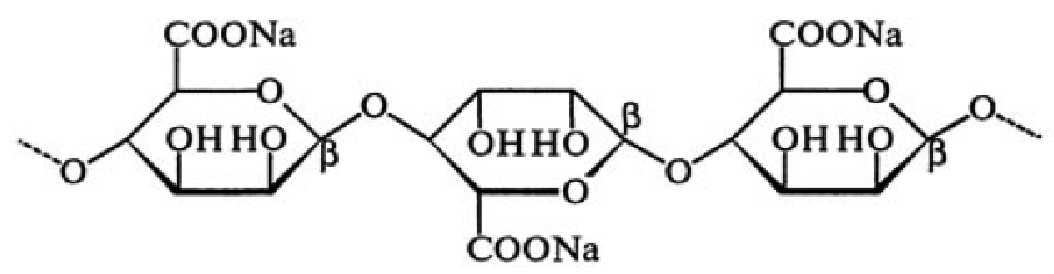

Figure 2. The structural formula of sodium alginate

Sodium alginate belongs to the family of unbranched double copolymers: residues of $\beta$-D-mannuric acid and $\alpha$-L-guluronic acid, connected by $1 \rightarrow 4$ glycosidic bonds. Due to its good water-holding capacity and water solubility its main use is related to the ability to form gel [14].

The presence of ionogenic groups in chitosan and sodium alginate which are capable to form intermolecular ion-ion and ion-dipole bonds creates a prerequisite for their use as components of the interpolymer complex.

The purpose of this work is to establish the patterns of formation and structure of the interpolymer complex based on natural polymers - chitosan (CS) and sodium alginate (AL).

\section{Experimental}

Chitosan is a commercial sample of Sigma-Aldrich (USA) with a medium viscosity molecular weight $(\mathrm{MW}=500 \mathrm{kDa})$, degree of deacetylation (DD $80 \%)$.

Sodium alginate is a commercial sample with a molecular weight $(440 \mathrm{kDa})$ (produced by SigmaAldrich (China)).

The synthesis of IPCs was carried out by mixing the solutions of $0.01 \mathrm{M}$ chitosan in $0.1 \mathrm{M}$ hydrochloric acid solution with $0.01 \mathrm{M}$ aqueous solution of sodium alginate in molar ratios of [CS]:[AL] $=[100: 0]$, [90:10], [80:20], [70:30], [60:40], [50:50], [40:60], [30:70], [20:80], [10:90], [0:100] (mol.\%) at a temperature range 293-298 K. The obtained mixture was vigorously stirred on a shaker (model LS 110, LOIP, Russia) for $0.5-1$ hours and kept for 1 day at room temperature, then it was centrifuged for 15 minutes at 3500 $\mathrm{rpm}$ and precipitate of IPC was filtrated. After washing the IPC with distilled water, the final product was lyophilized (FreeZone, Labconco, USA).

Conductometric study of the CS-AL interpolymer complex formation was carried out using the S230 Seven Compact Mettler Toledo (Switzerland).

The structure of the IPCs was established by IR spectroscopy. IR spectra were recorded on a Fouriertransform infrared spectrometer (FTIR) Carry 660 Agilent (USA) equipped with an ATR attachment in the range from 400 to $4000 \mathrm{~cm}^{-1}$.

The charge of IPCs particles was determined by dynamic light scattering (DLS) on a Zetasizer Nano ZS 90 (Malvern, UK) instrument.

Studies of the rheological properties (structural viscosity) of synthesized IPCs solutions were performed on a rotational viscometer RheolabQC, «Anton Paar» (Austria) with a working cylinder-cylinder unit in the range of shear stresses 3-600 $\mathrm{Pa}$ at room temperature.

Study of the mechanical characteristics of films from individual polymers, IPC-systems based on them was carried out at room temperature on the TAXT plus Texture analyzer (Stable MicroSystems, UK) instrument in compression mode using $\mathrm{P} / 5 \mathrm{~S}$ at a speed of $0.1 \mathrm{~mm} / \mathrm{s}$. For obtaining films the initial polymers and IPCs mixtures were poured onto the polymer substrate and evaporated at room temperature and normal atmospheric pressure till an air-dry state [15]. 


\section{Results and discussion}

Complexation in the system chitosan-sodium alginate was detected by a combination of physical and chemical methods.

The results of conductometric determination of electrical conductivity in the system chitosan — sodium alginate are presented in Figure 3.

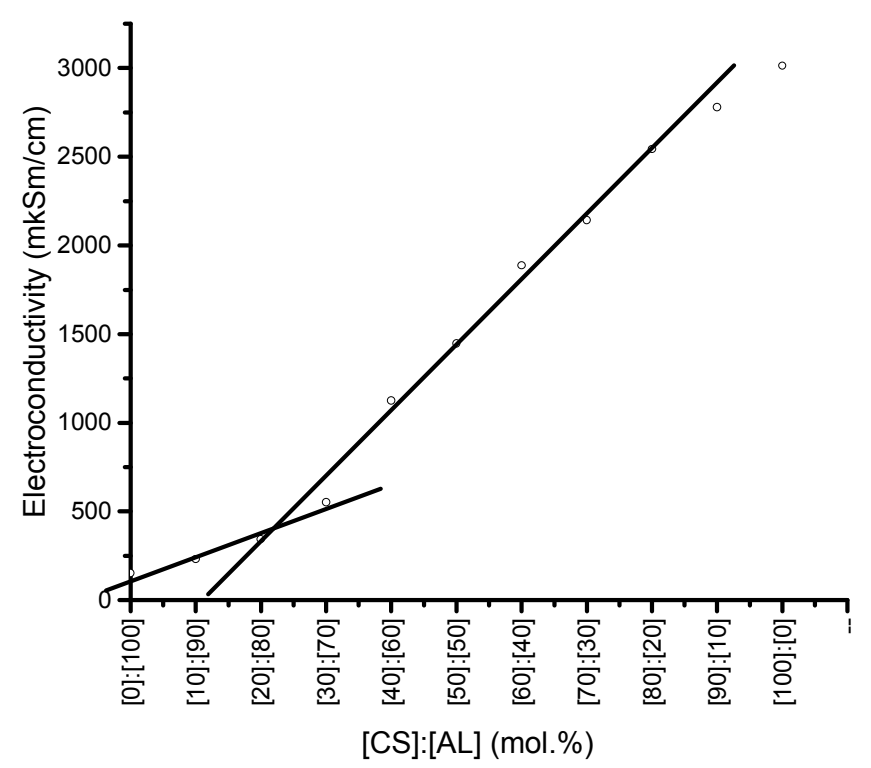

Figure 3. Conductometric titration curve in the CS-AL system

Figure 3 shows the conductometric titration curve of the chitosan-sodium alginate system at the molar ratios $[\mathrm{CS}]:[\mathrm{AL}]=[100: 0],[90: 10],[80: 20],[70: 30],[60: 40],[50: 50],[40: 60],[30: 70],[20: 80],[10: 90]$, $[0: 100]$ and at the ratio $[\mathrm{CS}]:[\mathrm{AL}]=[20]:[80]$ it has a pronounced bend, which according to the fundamentals of the physical and chemical analysis indicates on the formation of an individual compound - IPC with the composition $[\mathrm{CS}]:[\mathrm{AL}]=[1]:[4]$.

Evidence of the CS and AL complexation is the formation of a precipitate which is insoluble in water and acidic solutions. The formed precipitation of IPC was a white, odorless gel-like mass, stable during centrifugation; the maximum mass of the precipitate was determined by IPC with the [20]:[80] mol.\% ratio.

The masses of precipitates of IPCs after centrifugation are given in Table 1.

$\mathrm{Tab} l \mathrm{e} 1$

The masses of IPC precipitates after centrifugation

\begin{tabular}{|c|c|}
\hline$[\mathrm{CS}]:[\mathrm{AL}]$, mol.\% & $\begin{array}{c}\text { The mass of wet IPC } \\
\text { precipitates, } \mathrm{g}\end{array}$ \\
\hline$[10]:[90]$ & 0.0562 \\
\hline$[20]:[80]$ & 1.1825 \\
\hline$[30]:[70]$ & 1.1681 \\
\hline$[40]:[60]$ & 0.7730 \\
\hline$[50]:[50]$ & 0.5989 \\
\hline$[60]:[40]$ & 0.6537 \\
\hline$[70]:[30]$ & 0.5028 \\
\hline$[80]:[20]$ & 0.4215 \\
\hline$[90]:[10]$ & 0.3114 \\
\hline
\end{tabular}

Maximum mass of the IPC precipitates is observed for the molar ratio [CS]:[AL] $=[20]:[80]$ mol.\%, according to Table 1 .

The complexation in the chitosan - sodium alginate system was also confirmed by the dynamic light scattering (DLS) method. Dependence of the $\zeta$-potential of particles on the ratio in the system of CS-AL is shown in Figure 4. 


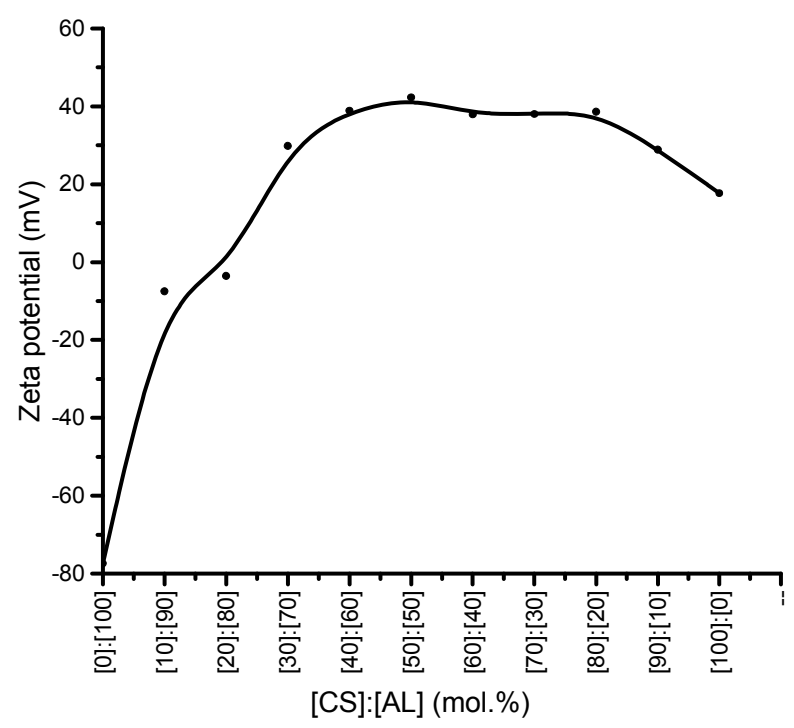

Figure 4. Dependence of the $\zeta$-potential of the IPC particles on the composition of [CS]: [AL]
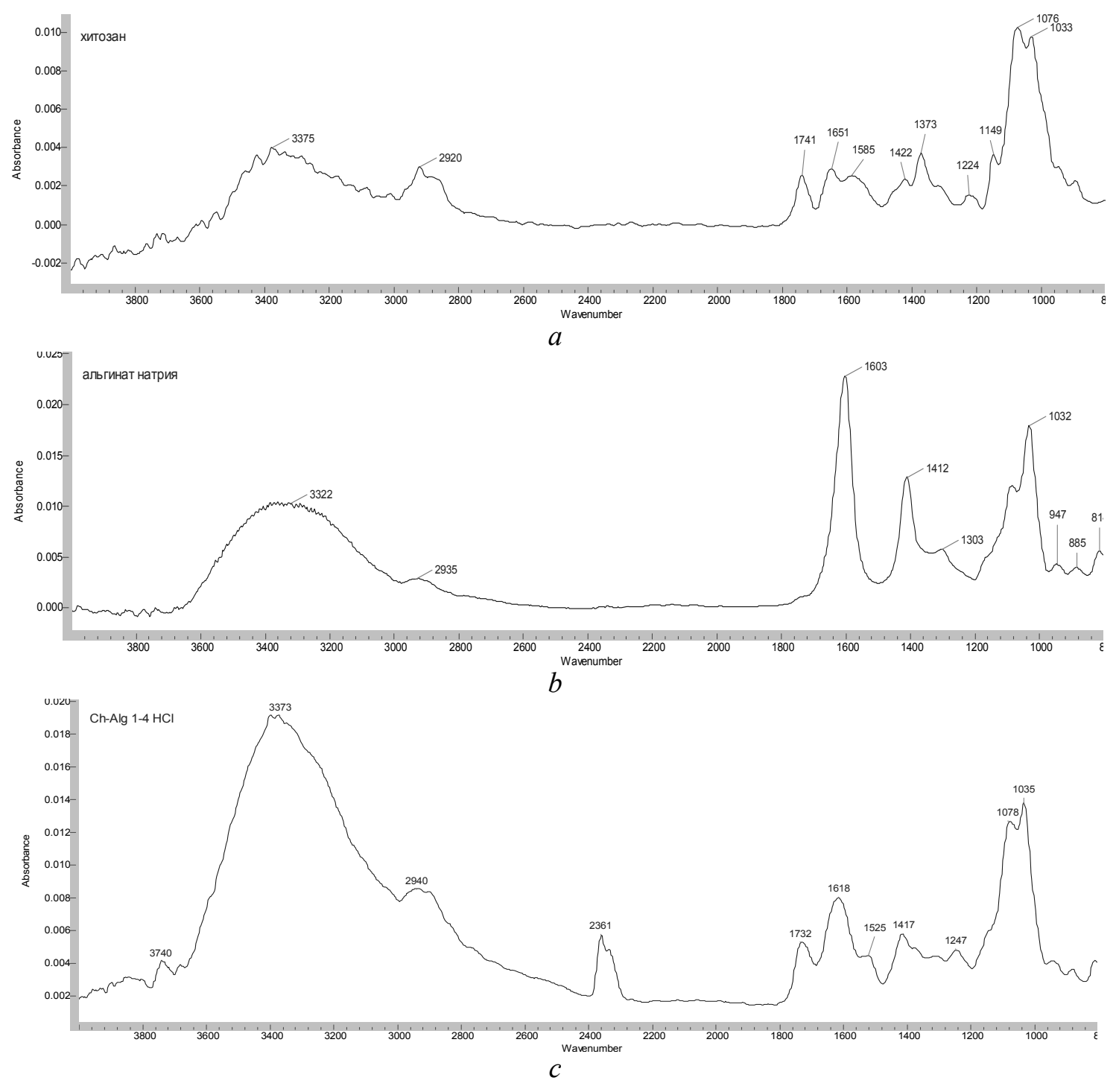

$a-\mathrm{CS} ; b-\mathrm{AL} ; c-\mathrm{IPC}$ of $\mathrm{CS} / \mathrm{AL}$

Figure 5. IR spectra 
At the molar ratio $[\mathrm{CS}]:[\mathrm{AL}]=[20]:[80] \zeta$-potential reaches zero value, as shown in Figure 4. It indicates the neutralization of the positive charge of chitosan by the negative charge of the carboxylic group of sodium alginate. This indicates the electrostatic interaction between the molecules of the polycation and the polyanion and the cooperative nature of complexation.

Data obtained using DLS correspond well with data of the IR Fourier spectroscopic investigation of complexation in the chitosan - sodium alginate system. IR spectra of CS, AL and IPCs based on them were obtained (Fig. $5 a, b, c$ ).

IR spectra of chitosan and alginate contain absorption bands that characterize all polysaccharides $3000-3500 \mathrm{~cm}^{-1}$ (vibrations of OH-groups), $2900-2950 \mathrm{~cm}^{-1}$ (vibrations of $\mathrm{CH}_{2}$-groups), 1010-1050 $\mathrm{cm}^{-1}$ (vibrations of $\mathrm{C}-\mathrm{O}-\mathrm{C}$ sugar groups). IR spectra of chitosan (Fig. 5, a) contains absorption bands in the $1651 \mathrm{~cm}^{-1}$ region $\left(\delta \mathrm{NH}_{2}\right)$, this is characteristic of amino groups. Absorption bands are observed in the 1603 and $1412 \mathrm{~cm}^{-1}$ region in IR spectra of alginate, it's due to the presence of carboxylate - ionic groups.

The main changes occur in the spectra of the absorption bands of $\mathrm{NH}_{2}$-groups and carboxyl groups in IR spectra of IPCs, which to point on their electrostatic interaction [16]. Main changes occur in the region of the spectrum of stretching vibrations of carboxyl groups $\left(1603\right.$ and $\left.1412 \mathrm{~cm}^{-1}\right)$ and deformation vibrations of the amino group $\left(1651 \mathrm{~cm}^{-1}\right)$, which during the formation of IPC lose their intensity and shift $\left(v^{\mathrm{sym}}{ }_{\mathrm{C}=\mathrm{O}}\right.$ $\left.1618 \mathrm{~cm}^{-1}, v_{\mathrm{C}=\mathrm{O}}^{\text {asym }} 1417 \mathrm{~cm}^{-1}\right)$.

Rheological properties of [CS]:[AL] IPCs mixtures were investigated. The rheological behavior of polymer systems is determined by the mechanism of their formation, for which the nature, location and interaction of the functional groups of the polymer matrix are particular importance [17].

Figure 6 shows the curve of shear stress dependence on the [CS]:[AL] molar ratio.

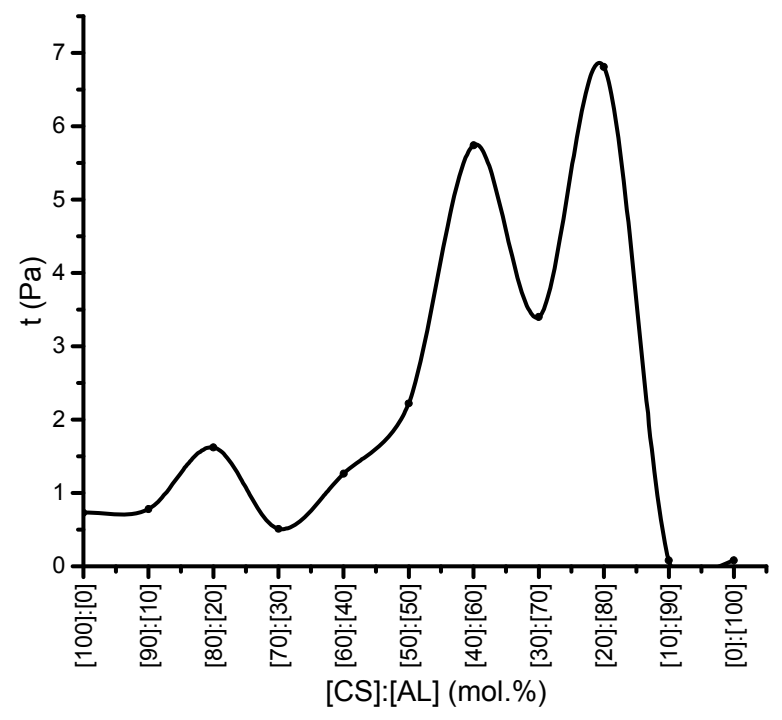

Figure 6. Dependence of the shear stress on the ratio [CS]: [AL]

As shown in Figure 6, the highest shear stress was in the complex solution with the molar ratio [CS]: $[\mathrm{AL}]=[20]:[80]$. It's due to the high degree of adhesion of branched structures and the intensity of intermolecular interactions of the initial polymers [18] and leads to a decrease of IPCs associates size and their strength.

The films based on IPCs of chitosan - alginate were prepared and their mechanical properties were studied. The period of film formation on the polymer substrate IPC [CS]:[AL] was 3 days. The mechanical characteristics of the molded films are shown in Table 2.

Mechanical characteristics of films from chitosan, sodium alginate and IPCs based on them

\begin{tabular}{|c|c|}
\hline Film composition & Elastic modulus, Pa \\
\hline AL & $3.52 \pm 0.05$ \\
\hline CS & $0.26 \pm 0.08$ \\
\hline IPC [CS]:[AL] $=[20]:[80]$ mol.\% & $2.27 \pm 0.06$ \\
\hline
\end{tabular}


The value of elastic modulus of the IPC $(2.27 \pm 0.06 \mathrm{~Pa})$ with the molar ratio [CS]:[AL] $=[20]:[80]$ prevails over the value of the chitosan modulus $(0.26 \pm 0.08 \mathrm{~Pa})$ and comparable with the elastic modulus of sodium alginate $(3.52 \pm 0.05 \mathrm{~Pa})$, as shown in Table 2. Mechanical strength is an important characteristic of the IPCs, because it is further intended to be used as a former of the soil. Therefore, they must be resistant to various loads and preserve the integrity of the structure.

\section{Conclusion}

Thus, as a result of complex physico-chemical studies, complexation was found in chitosan - sodium alginate system with the optimal composition of IPC [CS]:[AL] = [1]:[4]. This ratio for an interacting pair of polyelectrolytes characterizes the formation of non-stoichiometric IPCs. Alginate-chitosan polyionic complexes are formed due to the ion-ion interaction between the carboxyl groups of alginate and the amino groups of chitosan.

The work was carried out with the financial support of the Ministry of Education and Science of the Republic of Kazakhstan, grant AP05134681.

\section{References}

1 Mukhamedov G.I. Interpolymer complexes: structure, properties, application: monograph / G.I. Mukhamedov, S.Ya. Inagamov, M.M. Hafizov. — LAP Lambert Academic Publishing, 2017. — 295 p.

2 Kabanov V.A. Polyelectrolytes in the solution of ecological problems / V.A. Kabanov, A.B. Zezin, V.A. Kasaikin, A.A. Yaroslavov, D.A. Topchiyev // Russian Chem. Reviews. - 1991. — Vol. 60, No. 3. - P. $288-297$.

3 Ахмеджонов Д.Г. Эффективное использование интерполимерных комплексов при минерализации почв / Д.Г. Ахмеджонов, Х.Э. Туркменов, Х.Т. Бекмуродов // Молодой ученый. — 2016. — № 27. — С. 207, 208.

4 Абдиев К.Ж. Интерполимерное комплексообразование с участием полимеров, полученных на основе простых виниловых эфиров / К.Ж. Абдиев // Известия Национальной академии наук Республики Казахстан. Сер. хим. — 2008. — № 2. C. $31-38$.

5 Бовальдинова К.А. Получение и свойства «умных» чувствительных к давлению адгезивов на основе интерполимерных комплексов: дис. ... канд. хим. наук: 02.00 .06 - Высокомолекулярные соединения / К.А. Бовальдинова. — М., 2018. $165 \mathrm{c}$.

6 Rhazi M. Influence of the nature of the metal ions on the complexation with chitosan. Application to the treatment of liquid waste / M. Rhazi, J. Tolaimate, M. Rinaudo, P. Vottero, A. Alagui, M. Meray // European Polymer Journal. — 2002. — Vol. 38, No. 8. - P. 1523-1530.

7 Riccardo A.A. Genipin - crosslinked chitosan hydrogels as biomedical and pharmaceutical aids / A.A. Riccardo // Carbohydrate Polymers. - 2009. - No. 77. - P. 1-9.

8 Kumari R. Physico-chemical and biological activity study of genipin cross linked chitosan scaffolds prepared by using supercritical carbon dioxide for tissue engineering applications / R. Kumari, P.K. Dutta // International J. Biological Macromolecules. 2010. - No. 46. - P. 261-266.

9 Muzzarelli Riccardo A.A. Chitins and chitosans for the repair of wounded skin, nerve, cartilage and bone / Riccardo A.A. Muzzarelli // Carbohydrate Polymers. — 2009. - No. 76. - P. 167-182.

10 Хитин и хитозан: получение, свойства и применение / под ред. К.Г. Скрябина, Г.А. Вихоревой, В.П. Варламова. М.: Наука, 2002. - 368 с.

11 Krayukhina M.A. Polyelectrolyte complexes of chitosan: formation, properties and applications / M.A. Krayukhina, N.A. Samoilova, I.A. Yamskov // Russian Chemical Reviews. - 2008. - Vol. 77, No. 9. - P. 799-813.

12 Berkovich L.A. Hydrodynamic and conformational parameters of chitosane / L.A. Berkovich, G.I. Timofeyeva, M.P. Tsyurupa, V.A. Davankov // Polymer Science U.S.S.R. - 1980. — Vol. 22, No. 8. - P. 2009-2018.

13 Gamzazade A.I. On the viscosity properties of chitosan solutions / A.I. Gamzazade, A.M. Sklyar, S.-S.A. Pavlova, S.V. Rogozhin // Polymer Science U.S.S.R. — 1981. — Vol. 23, No. 3. — P. 665-669.

14 Usov A.I. Alginic acids and alginates: analytical methods used for their estimation and characterisation of composition and primary structure / A.I. Usov // Russian Chemical Reviews. — 1999. — Vol. 68, No. 11. — P. 957-966.

15 Инагамов С.Я. Интерполимерные комплексы на основе натрийкарбоксиметилцеллюлозы - носители наночастиц / С.Я. Инагамов, Ф.С. Каюмходжаев, А.А. Абзалов // Научное обозрение. Биологические науки. — 2017. — № 2. - С. $71-74$.

16 Петропавловский Г.А. Гидрофильные частично замещенные эфиры целлюлозы и их модификация путем сшивания / Г.А. Петропавловский. - Л.: Наука, 1988. - 295 с.

17 Юсова А.А. Свойства гидрогелей на основе смесей альгината натрия с другими полисахаридами природного происхождения / А.А. Юсова, И.В. Гусев, И.М. Липатова // Химия растительного сырья. — 2014. — № 4. - С. 59-66.

18 Kabanov V.A. Polyelectrolyte complexes in solution and in bulk / V.A. Kabanov // Russian Chem. Reviews. - 2005. Vol. 74, No. 1. - P. 3-20. 
Ж.С. Қасымова, Л.К. Оразжанова, Б.Б. Баяхметова, Б.С. Гайсина, Н.Б. Қасенова, Г.Т. Елемесова

\title{
Хитозан мен натрий альгинаты негізінде интерполимерлік комплекстерді алу
}

\begin{abstract}
Алғаш рет жаңа арзан және биоыдырайтын топырақ құрылымтүзгіштер - табиғи полимерлер негізіндегі интерполимерлік комплекстерді (ИПК) синтездеу әдісі әзірленді. Экологиялық мәселелерді шешу мақсатында интерполимерлік комплекстің құрылымдық компоненттері ретінде тірі ұлпалармен биоүйлесімді, биоинертті табиғи полимерлер - хитозан (ХT3) мен натрий альгинаты (АЛNa) полисахаридтері қолданылды. Хитозан - натрий альгинаты интерполимерлік комплексі берілген қатынаста полимерлердің эквимолярлы ерітінділерін қосу әдісімен алынды. Алынған интерполимерлік комплекстердің құрамы мен қасиеттері - масса, электрөткізгіштік, механикалық және реологиялық қасиеттері, бөлшектердің өлшемі мен заряды, құрылымы физика-химиялық талдау әдістермен (реовискозиметрия, механикалық талдау, гравиметрия, потенциометрлік және кондуктометрлік титрлеу, динамикалық жарық шашырау (ДЖШ) және ИҚ-Фурье спектроскопия) анықталды. Интерполимерлік комплекс құрамы ХТЗ-АЛNa $=1: 4$. Стехиометриялық емес интерполимерлік комплекс ион-иондық өзара әрекеттесу нәтижесінде пайда болатыны байқалды. ХТЗ-АЛNa ИПК негізінде полимерлік жабындар алындып, олардың механикалық қасиеттері анықталды. Интерполимерлі комплекс негізіндегі жабындардың механикалық беріктілігі жеке полимерлердің жабындармен салыстырғанда жоғары; бұл алынған полимерлі жүйені топырақтың жел мен судың әсерінен миграциясына жол бермеу үшін қолдануға болатын перспективті материалдар жасауға мүмкіндік береді.
\end{abstract}

Кілт сөздер: комплекс түзу, биополимерлер, хитозан, натрий альгинаты, құрам, стехиометриялық емес комплекс, жабындар, полиионды комплекс.

\author{
Ж.С. Касымова, Л.К. Оразжанова, Б.Б. Баяхметова, \\ Б.С. Гайсина, Н.Б. Касенова, Г.Т. Елемесова
}

\section{Получение интерполимерных комплексов на основе хитозана и альгината натрия}

\begin{abstract}
Впервые разработана методика синтеза новых дешевых и биоразлагаемых структурообразователей почв - интерполимерного комплекса (ИПК) на основе природных полимеров. В качестве структурных компонентов интерполимерного комплекса для решения экологических проблем были использованы биосовместимые с живыми тканями биоинертные природные полимеры - полисахариды хитозан (XT3) и альгинат натрия (АЛNa). Интерполимерный комплекс хитозан - альгинат натрия был получен методом смешения эквимолярных растворов полимеров в заданной пропорции. Методами физико-химического анализа (реовискозиметрии, механического анализа, гравиметрии, потенциометрического и кондуктометрического титрований, динамического лазерного светорассеяния (ДЛС) и ИКФурье спектроскопии) определены состав и свойства полученных полимерных комплексов - масса, электропроводность, механические свойства, реологические свойства, размеры и заряд частиц, структура. Состав интерполимерного комплекса [ХT3]:[АЛNa] = 1:4. Обнаружено, что формирование интерполимерного нестехиометрического комплекса происходит в результате ион-ионных взаимодействий. Получены полимерные пленки на основе ИПК ХТЗ-АЛNa, и определены их механические свойства. Установлено, что механическая прочность пленок на основе интерполимерного комплекса выше в сравнении с пленками отдельных полимеров, что делает данную полимерную систему перспективным материалом в целях использования для предотвращения ветровой и водной миграции земель.
\end{abstract}

Ключевые слова: комплексообразование, биополимеры, хитозан, альгинат натрия, состав, нестехиометрический комплекс, пленки, полиионные комплексы.

\section{References}

1 Mukhamedov, G.I. (2017). Interpolymer complexes: structure, properties, application. LAP Lambert Academic Publishing.

2 Kabanov, V.A., Zezin, A.B., Kasaikin, V.A., Yaroslavov, A.A. \& Topchiyev, D.A. (1991). Polyelectrolytes in the solution of ecological problems. Russian Chem. Reviews, 60(3), 288-297.

3 Ahmedzhonov, D.G., Turkmenov, H.E., \& Bekmurodov, H.T. (2016). Effektivnoe ispolzovanie interpolimernykh kompleksov pri mineralizatsii pochv [Efficient use of interpolymer complexes during soil mineralization]. Molodoi uchenyi - Young scientist, 27, 207-208 [in Russian].

4 Abdiev, K.Zh. (2008). Interpolimernoe kompleksoobrazovanie s uchastiiem polimerov, poluchennykh na osnove prostykh vinilovykh efirov [Interpolymer complexation involving polymers derived from vinyl ethers]. Izvestiia Natsionalnoi akademii nauk 
Respubliki Kazakhstan. Seriia khimicheskaia, — News of the National Academy of Sciences of the Republic of Kazakhstan. Chemical series, 2, 31-38 [in Russian].

5 Bovaldinova, K.A. (2018). Poluchenie i svoistva «umnykh» chuvstvitelnykh $\mathrm{k}$ davleniiu adhezivov na osnove interpolimernykh kompleksov [Obtaining and properties of «smart» pressure-sensitive adhesives based on interpolymer complexes]. Candidate's thesis. Moscow [in Russian].

6 Rhazi, M., Tolaimate, J., Rinaudo, M., Vottero, P., Alagui, A., \& Meray, M. (2002). Influence of the nature of the metal ions on the complexation with chitosan. Application to the treatment of liquid waste. European Polymer Journal, 38(8), $1523-1530$.

7 Riccardo, A.A. (2009). Genipin - crosslinked chitosan hydrogels as biomedical and pharmaceutical aids. Carbohydrate Polymers, 77, 1-9.

8 Kumari, R., \& Dutta, P.K. (2010). Physico-chemical and biological activity study of genipin cross linked chitosan scaffolds prepared by using supercritical carbon dioxide for tissue engineering applications. International J. Biological Macromolecules, 46, 261-266.

9 Muzzarelli, Riccardo A.A. (2009). Chitins and chitosans for the repair of wounded skin, nerve, cartilage and bone. Carbohydrate Polymers, 76, 167-182.

10 Skriabin, K.G., Vihoreva, G.A., \& Varlamov, V.P. (2002). Khitin i khitozan: poluchenie, svoistva i primenenie [Chitin and chitosan: preparation, properties and application]. Moscow: Nauka [in Russian].

11 Krayukhina, M.A., Samoilova, N.A., \& Yamskov, I.A. (2008). Polyelectrolyte complexes of chitosan: formation, properties and applications. Russian Chemical Reviews, 77(9), 799-813.

12 Berkovich, L.A., Timofeyeva, G.I., Tsyurupa, M.P., \& Davankov, V.A. (1980). Hydrodynamic and conformational parameters of chitosane. Polymer Science U.S.S.R., 22(8), 2009-2018.

13 Gamzazade, A.I., Sklyar, A.M., Pavlova, S.-S.A., \& Rogozhin, S.V. (1981). On the viscosity properties of chitosan solutions. Polymer Science U.S.S.R., 23(3), 665-669.

14 Usov, A.I. (1999). Alginic acids and alginates: analytical methods used for their estimation and characterization of composition and primary structure. Russian Chemical Reviews, 68(11), 957-966.

15 Inagamov, S.Ya., Kaiumhodiaiev, F.S., \& Abzalov, A.A. (2017). Interpolimernye kompleksy na osnove natriikarboksimetiltselliulozy - nositeli nanochastits [Sodium carboxymethylcellulose based interpolymer complexes are carriers of nanoparticles]. Nauchnoe obozrenie. Biolohicheskie nauki - Scientific Review. Biological Sciences, 2, 71-74 [in Russian].

16 Petropavlovskii, G.A. (1988). Hidrofilnye chastichno zameshchennye efiry tselliulozy i ikh modifikatsiia putem sshivaniia [Hydrophilic partially substituted cellulose ethers and their modification by crosslinking]. Leningrad: Nauka [in Russian].

17 Iysova, A.A., Gusev, I.V., \& Lipatova, I.M. (2014). Svoistva hidrohelei na osnove smesei alhinata natriia s druhimi polisakharidami prirodnoho proiskhozhdeniia [Properties of hydrogels based on mixtures of sodium alginate with other polysaccharides of natural origin]. Khimiia rastitelnoho syria. - Chemistry of plant materials, 4, 59-66 [in Russian].

18 Kabanov, V.A. (2005). Polyelectrolyte complexes in solution and in bulk. Russian Chem. Reviews, 74(1), 3-20. 